Article

\title{
Mechanisms of Grazing Management in Heterogeneous Swards
}

\author{
Arthur Pontes-Prates ${ }^{1,2, *}$, Paulo César de Faccio Carvalho ${ }^{2} \mathbb{D}$ and Emilio Andrés Laca ${ }^{1}$ (D) \\ 1 Department of Plant Sciences, UC Davis, Davis, CA 95616, USA; ealaca@ucdavis.edu \\ 2 Grazing Ecology Research Group, UFRGS, Porto Alegre, RS 90040-060, Brazil; paulocfc@ufrgs.br \\ * Correspondence: pontesprates@ucdavis.edu
}

Received: 20 August 2020; Accepted: 15 October 2020; Published: 19 October 2020

check for updates

\begin{abstract}
We explored the effects of heterogeneity of sward height on the functioning of grazing systems through a spatially implicit mechanistic model of grazing and sward growth. The model uses a population dynamic approach where a sward is spatially structured by height, which changes as a function of defoliation, trampling, and growth. The grazing component incorporates mechanisms of bite formation, intake, and digestion rates, but excludes sward quality effects. Sward height selection is determined by maximization of the instantaneous intake rate of forage dry mass. For any given average sward height, intake rate increased with increasing spatial heterogeneity. Spatio-temporal distribution of animal density over paddocks did not markedly affect animal performance but it modified the balance of vegetation heterogeneity within and between paddocks. Herbage allowance was a weak predictor of animal performance because the same value can result from multiples combinations of herbage mass per unit area, number of animals, animal liveweight, and paddock area, which are the proximate determinants of intake rate. Our results differ from models that assume homogeneity and provide strong evidence of how heterogeneity influences the dynamic of grazing systems. Thus, we argue that grazing management and research need to incorporate the concept of heterogeneity into the design of future grazing systems.
\end{abstract}

Keywords: grazing management; sward height distribution; spatial heterogeneity; ecological modeling; grazing behavior; resource heterogeneity; integral projection matrix

\section{Introduction}

Traditional grazing management has been based on variables such as stocking rate and herbage allowance, aimed at controlling intensity and frequency of defoliation, and consequently, herbage production and animal performance. However, these approaches assume equilibrium conditions and disregard spatial heterogeneity and scaling effects present in grazing systems [1]. Herbage allowance and stocking rate may only describe an instant of a grazing system, but not its dynamics, which result from multiple processes influenced by biotic and abiotic factors. The actual management variables over which we can exert control are shape and area of paddocks, number and characteristics of animals, and timing and duration of grazing and rest periods. Additional management variables such as fertilization and irrigation timing and rate can also be used to modify the quality and dynamics of vegetation state variables. Likewise, livestock distribution and behavior can be altered through rewards like salt or supplements. These management and uncontrollable biotic and abiotic factors change over space and time and drive grazing systems into a permanent state of flux.

Defoliation intensity in one biting event is usually the proportion of the plant mass that is in the top half of the sward height at the bite location. Sheep and cattle have a remarkable constant bite depth that is about $50 \%$ of sward height, across a large variety of conditions [2,3]. Thus, the mechanism of unitary defoliation intensity is not yet directly susceptible to management. Management variables can 
only affect the probability that any given plant will be defoliated at any moment. Actual defoliation frequency depends not only on exposure to grazing but also on the spatial patterns of bites that animals choose $[4,5]$. For example, large-scale patterns of what appears to be defoliation intensity, such as the exponential increase in height with increasing distance from water [6], are most likely patterns created by the balance between plant growth and defoliation frequency. Because animals have to walk to water frequently, the actual density of livestock occupancy decreases with increasing distance from water.

Although traditional grazing management considers the temporal heterogeneity of forage demand and supply, the concept of spatial heterogeneity has not been fully incorporated, perhaps because is harder to perceive and to control. Livestock distribution has fractal properties and is in part determined by the heterogeneity of resources such as forage, water, and shade [7,8]. In addition to the inherent heterogeneity, grazing disturbance (as well trampling and excreta deposition) is an important source of variability in the vegetation $[9,10]$ because herbivores' selectivity generates a mosaic of tall and short patches that in turn affect future grazing. Sward growth rate is nonlinear, and therefore pasture production is not fully determined by average sward height at paddock scale but also depends on the spatial distribution of sward height [11,12] (Figure A1). From an animal perspective, resource heterogeneity allows the selection of a diet that is better than the average available in the environment. Therefore, predictions of pasture production and animal intake and performance on models that assume homogeneity tend to differ from reality [13].

Grazing systems are complex and vary in time and space, requiring a broader approach than has been applied to grazing management due to their multidimensional nature. However, traditional grazing management variables such as average sward height, stocking rate, and herbage allowance disregard the effects of heterogeneity and scaling on the functioning of grazing systems. We aimed to develop a spatially implicit model of grazing and sward growth to explore the effects of spatial heterogeneity on responses to traditional grazing management variables. We simulated three grazing conditions using traditional management variables to determine the interaction between inherent spatio-temporal scales of grazing with those imposed by management in heterogeneous swards. We tested the hypotheses that (1) the functional response (instantaneous intake rate) is related not only to resource abundance but also to resource heterogeneity; (2) system performance (yield per animal and per unit area) responds to spatio-temporal distribution of animal density; and that (3) herbage allowance is not sufficient as a measure to manage animal performance because any value of herbage allowance can be obtained for any given level of forage abundance simply by changing the number of animals or the area of the paddock. This work contributes to the understanding of how heterogeneity and scaling influence the functioning of grazing systems and provides a promising platform for future research.

\section{Materials and Methods}

\subsection{Model Description}

We developed a dynamic mechanistic model of grazing where the sward is structured by height. The grazing component of the model incorporates detailed mechanisms of bite dimensions and intake rate as controlled by ingestion and digestion. Model inputs are management variables such as species and number of animals, paddock area, timing and duration of grazing and rest periods, and initial state variables: sward height distribution (amount of area in 2000 bins of sward height), rumen fill, and body mass.

The approach was to include all major grazing mechanisms known and to determine their logical consequences by integration into the model. The model is spatially implicit because it simulates the heights of a population of plants, but their positions are not specified. Diet quality is assumed to be constant and unrelated to the heights selected for grazing. This assumption is meant to eliminate quality as a factor driving selectivity in this version of the model, and it has no impact on the growth of the model swards, as we use an empirical equation based on real swards to model growth in 
height. The model tracks defoliation, trampling, and growth of plants in 2000 height classes, as well as selectivity and individual bite dimensions, time, and mass in a $10 \mathrm{~min}$ time step.

A key feature of grazing systems is the large difference in temporal scale of growth and defoliation at the individual plant level, a feature that is not contemplated in typical difference or differential equation models (e.g., $[14,15])$. In the present model we implement the difference in the temporal scales of grazing and growth by representing grazing as a death-birth process by which every bite "kills" an area of pre-grazing height and "gives birth" to an equal area with the corresponding post-grazing height. The integration of both spatial heterogeneity in height and pasture growth with animal behavior and productivity at a high temporal resolution, as well as the use of the integral projection matrix technique, are the main novel features that distinguish this model from similar grazing models that include resource heterogeneity (e.g., [4,16-21]).

Sward structure is represented in the model by the horizontal and vertical distribution of plant mass. The horizontal structure is represented by the frequency distribution of heights, and the vertical structure is described by an exponential decline in bulk density from the bottom to the top of the canopy [22,23]. Sward height distribution is updated every $10 \mathrm{~min}$ using an integral projection matrix model (a modeling approach that uses transition matrices to calculate the change in state of a population structured by a continuous variable) adapted from Ellner et al. [24]. Sward areas increase in height according to a temperature-dependent logistic growth process [25] and decrease in height by grazing and trampling with rates that depend on sward height and animal density. Using the original population dynamics view of the integral projection method, the process can be viewed as discrete areas growing into adjacent bins of taller height, or "dying" due to being grazed and trampled and being instantly "reborn" in a bin with a shorter height equal to the remaining stubble. Grazed areas are reborn at half (or another selected proportion) of the original height, whereas trampling effects are simulated by reducing $7.5 \%$ of the searched area to a height of $25 \mathrm{~mm}$. Area trampled is commensurate with hoof area and number of steps per unit area searched [26], whereas trampled height is based on measurements of ryegrass plants lodged after grazing (Carvalho, unpublished data). The effect of excreta deposition on area available for grazing is partly accounted for by the trampled area, but the model does not currently focus on the effects of excreta on animal selectivity, and it does not include excreta effects on plant growth. Relative growth rate, height of trampled sward, and nutritive value were parameterized for annual ryegrass (Lolium multiflorum L.), whereas vertical distribution was parameterized with both annual and perennial ryegrass (Lolium perenne L.) data. The actual hourly temperature used for simulations was obtained from the experimental station in Federal University of Rio Grande do Sul, Brazil, for the growing period.

The beginning and end of grazing bouts are determined by rumen fill and an empirical circadian rhythm of grazing motivation. The circadian rhythm is an empirical function that defines the proportion of time that the animals are actually grazing within feeding bouts [27]. Rumen fill is a state variable whose rate of change is the difference between intake rate and digestion and passage rates. Digestion rate is constant, whereas passage rate is a linear function of instantaneous intake rate [28,29]. Grazing ceases when the rumen becomes full and it resumes when rumen fill falls below $90 \%$ of rumen capacity and circadian motivation is on. Rumen capacity is an isometric function of body mass [30] and it increases by $30 \%$ between 16 and $24 \mathrm{~h}$ as a mechanism to avoid nocturnal grazing [31]. Only one canonical animal is simulated, and the results are simply multiplied by the number of animals.

Instantaneous intake rate is the product of the amount of herbage mass consumed divided by the sum of searching and handling time, assuming that searching and handling are mutually exclusive behaviors. Herbage mass consumed is calculated from elementary processes that define bite dimensions as functions of sward height and vertical mass distribution. Bite volume is the product of bite depth and bite area, where bite depth is a constant proportion of $50 \%$ of sward height $[2,3]$ and bite area is a function of sward height, herbage bulk density, and incisor arcade width [20]. The incisor arcade is determined by an allometric relationship with body mass [32]. Handling time, the sum of bite prehension time and chewing time, is a linear function of bite mass where the intercept is the time 
associated with prehension and chewing time is proportional to bite mass [3,33]. Searching time is determined by search path width and linear speed while walking during grazing [34].

The pattern of attack (i.e., the proportion of area of each height encountered that is selected for biting) is determined by maximization of the instantaneous intake rate [35]. At each time step, potential bites available are ranked according to profitability and incorporated into the selected diet in decreasing rank until the maximum intake rate is achieved. A sigmoidal curve centered at the shortest height selected serves to introduce "errors" or variability in the discrimination of bites, whereby some proportion of suboptimal bites is selected and some proportion of optimal bites is rejected.

Animal body mass is a state variable whose rate of change is determined by energy balance. Energy consumed is partitioned into maintenance and growth. The maintenance requirement is allometrically related to body mass, and energy expenditure increases by $30 \%$ during grazing $[36,37]$. Depending on its sign, remaining net energy is either met by weight loss or used for weight gain $[38,39]$.

\subsection{Simulations}

In order to test whether the model gives reasonable results, we compared predicted instantaneous intake rate values with observed values according to the procedure proposed by Piñeiro et al. [40]. We set up the simulation with the management variables used by Orr et al. [41]: 12 yearling cattle weighing $248 \mathrm{~kg}$, and average sward height ranging between 77 and $376 \mathrm{~mm}$. Sward height was assumed to have a coefficient of variation of $10 \%$. Simulations lasted $1 \mathrm{~h}$ such as in the experiment. The paddock area was set at 0.5 ha.

Three additional sets of simulations were performed. First, we examined the role of the heterogeneity of sward height on the functional response in $450 \mathrm{~kg}$ cattle by simulating $1 \mathrm{~h}$ of grazing in $300 \mathrm{~m}^{2}$ paddocks, with average sward height ranging between 25 and $300 \mathrm{~mm}$ and different coefficients of variation representing levels of heterogeneity. The simulations took place between 16:00 and 17:00, when circadian motivation is high, and the initial state of rumen fill was $70 \%$ of the maximum capacity to ensure grazing activity. Paddock size was dimensioned to avoid sward depletion greater than $5 \%$ of the average initial height. The response variable was the average intake rate over the grazing session.

Second, we tested the hypothesis that different spatio-temporal distributions of animal density result in different productivity by simulating a gradient of an increasing number of pasture strips $(1,2$, 3,6 , and 30 strips) and an increasing number of sheep $(180,270$, and 360$)$ in a 6 ha pasture. Each strip had a fixed period of occupation equal to the total grazing period of 30 days divided by the number of strips. The length of the resting period for each treatment was 30 days minus the period of occupation. All simulations started with a sward height distribution of $100 \pm 15 \mathrm{~mm}$ and sheep weighing $50 \mathrm{~kg}$. The response variables calculated were average daily gain and gain per unit area.

Third, we studied the impact of the "put-and-take" technique [42] to control herbage allowance when herbage mass per unit area changes when a single paddock is grazed continuously. Herbage allowance is defined as herbage mass per unit animal mass at an instant [43]. The "put-and-take" technique consists of varying the number of animals in the paddock to meet pre-established herbage allowance targets [42]. This simulation focuses on the consequences of adjusting herbage allowance by changing stocking density through changes in paddock size. We simulated a factorial arrangement of three herbage allowances $\left(0.7,1\right.$, and $\left.1.5 \mathrm{~kg} \mathrm{DM}(\mathrm{kg} \mathrm{BW})^{-1}\right)$ with three paddock sizes $(1,2.5$, and $5 \mathrm{ha}$ ) grazed for 120 days. Herbage allowance treatments were chosen based on the range usually recommended for cool-season grasses [44]. All treatments started with 12 cattle weighing $250 \mathrm{~kg}$. Herbage allowance targets were maintained by adjusting the number of animals every 30 days. The response variables were body mass over time and cumulative relative gain per unit area, calculated by multiplying body mass by number of animals and dividing by paddock area. 


\section{Results}

The model simulated instantaneous intake rate reasonably well, agreeing with experimental results by Orr et al. [42]. Observed and predicted intake rate values (Figure 1) were similar for intermediate values. Predictions underestimated high intake rates.

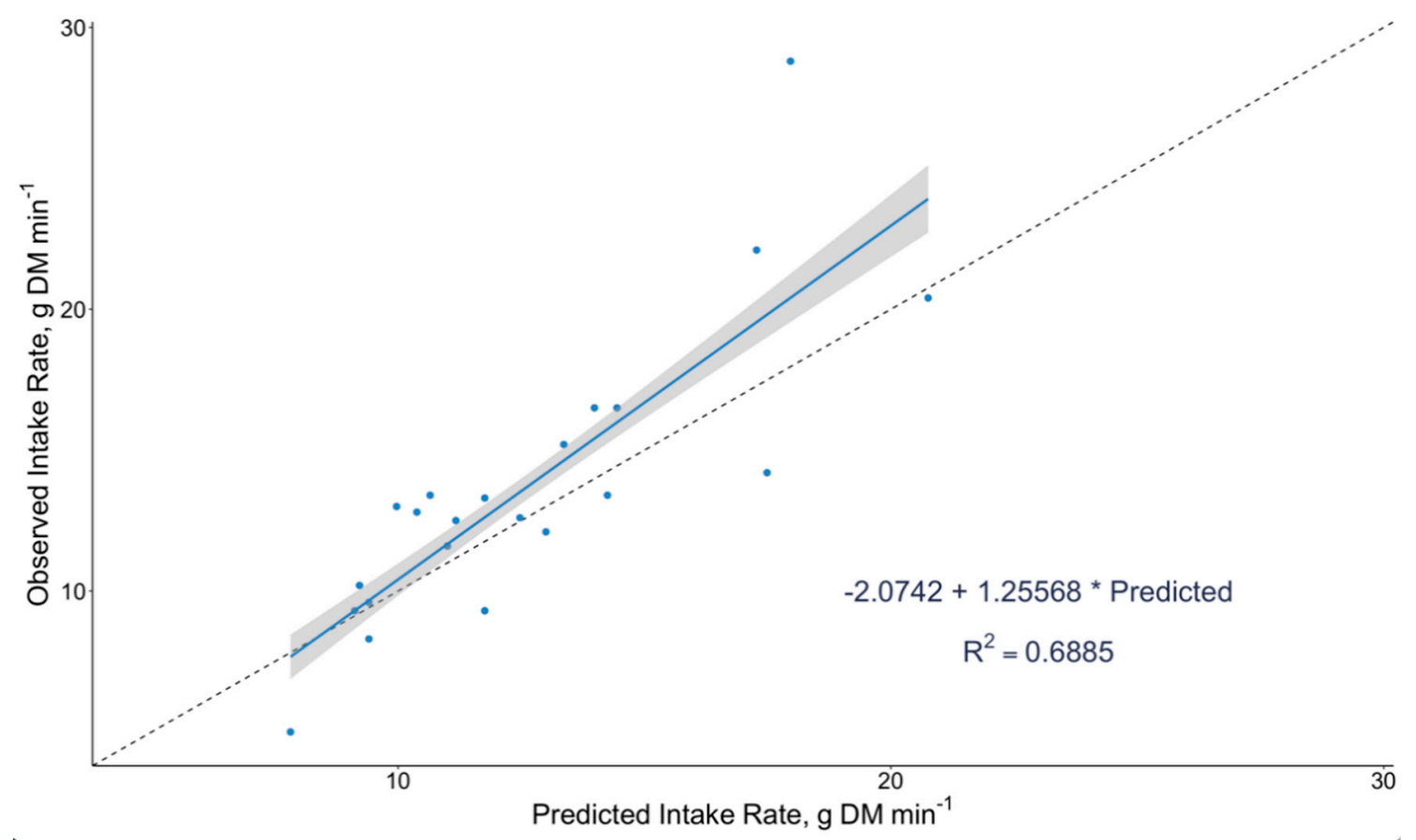

Figure 1. Relationship between observed intake rate and predicted values. Observed values are from Orr et al. [41].

This test is not a validation, but simply demonstrates the ability of the model to generate realistic results. We chose intake rate as the response variable because it plays a central role in the rate of herbage consumption and disappearance, and in animal performance. These results and multiple comparisons between observed and predicted values for several other experiments indicate that the model is suitable for our goals.

\subsection{Functional Response and Sward Heterogeneity}

In the first simulation set, the intake rate increased faster with increasing average sward height in swards with a greater coefficient of variation of height (Figure 2). The effect of heterogeneity was greatest for intermediate sward heights. For example, when the average height was $100 \mathrm{~mm}$, the intake rate in a homogeneous sward was about $21 \mathrm{~g} \mathrm{DM} \mathrm{min}^{-1}$, whereas a sward with a coefficient of variation of $100 \%$ resulted in an intake rate of $35 \mathrm{~g} \mathrm{DM} \mathrm{min}^{-1}$. The size of the effect of sward heterogeneity first increased and then declined with increasing sward height because at low average height, all heights available severely constrain bite mass, whereas in the tallest swards, intake rate is constrained by the rate of chewing and it becomes saturated. 




Figure 2. Functional response in cattle grazing swards with an increasing coefficient of variation of sward height distribution. The slopes were calculated between 25 and $75 \mathrm{~mm}$ for simulations with coefficients of variation of 0 and 100 .

The differences are explained by the pattern of attack or selectivity over height (Figure 3). As a result of the maximization of the intake rate, grazing swards with low heterogeneity, animals exhibited little selectivity and took bites from most of the heights available. In swards with greater heterogeneity, they selected the taller end of the distribution. For example, when average sward height was $125 \mathrm{~mm}$ with a coefficient of variation of $10 \%$, the shortest selected height was $108 \mathrm{~mm}$ and the intake rate was $26 \mathrm{~g} \mathrm{DM} \mathrm{min}^{-1}$, whereas with a coefficient of variation of $50 \%$ the shortest selected height was $120 \mathrm{~mm}$ and the intake rate was $29 \mathrm{~g} \mathrm{DM} \mathrm{min}^{-1}$.



Figure 3. Sward height distribution and pattern of attack with average sward height of $125 \mathrm{~mm}$ and coefficients of variation of 10 and $50 \%$. Both distributions (top and bottom) have the same average height but different coefficients of variation. The pattern of attack (sigmoidal orange curve) indicates the probability that an encountered area of a given height will be selected and bitten. On the top plateau of the line $100 \%$ of heights are selected, whereas at the bottom plateau $100 \%$ are rejected. The center of the almost vertical part of the curve indicates the shortest height that should be selected based on the maximization of the intake rate. 


\subsection{Spatio-Temporal Distribution of Grazing}

In the second simulation set, intake and body mass responses over time were influenced by the interaction of the number of strips and stocking density. The two highest numbers of animals clearly exceeded the pasture capacity and animals started losing weight shortly after the initial standing crop was depleted, regardless of the resting period allowed for each strip (Figure 4).

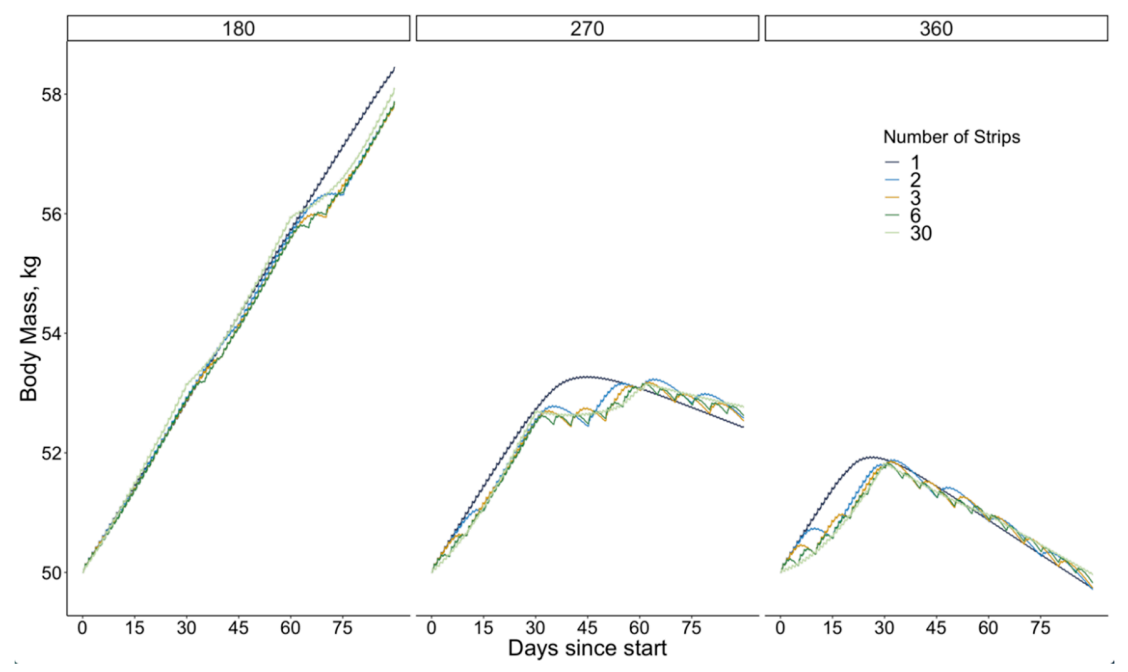

Figure 4. Effect of spatial distribution of animal density (number of strips) on body mass throughout the 90-day grazing season with 180, 270, and 360 sheep in 6 ha pastures. Different lines represent the different number of strips into which each grazing area was subdivided. Curves represent three grazing cycles wherein each strip was grazed a total of three times.

Although animals in continuous stocking (one strip) exhibited slightly higher body mass during certain periods, average daily gain and total gain per ha were fairly similar for all treatments within each stocking rate (Figure 5). For instance, at the lowest number of animals the relative average daily gain was only $7 \%$ less with six strips than with one. Average sward height (calculated for each $12 \mathrm{~h}$ period) for each strip was similar for each number of animals, but a greater number of strips promoted more heterogeneity among strips and homogeneity within strips (Figure 6).

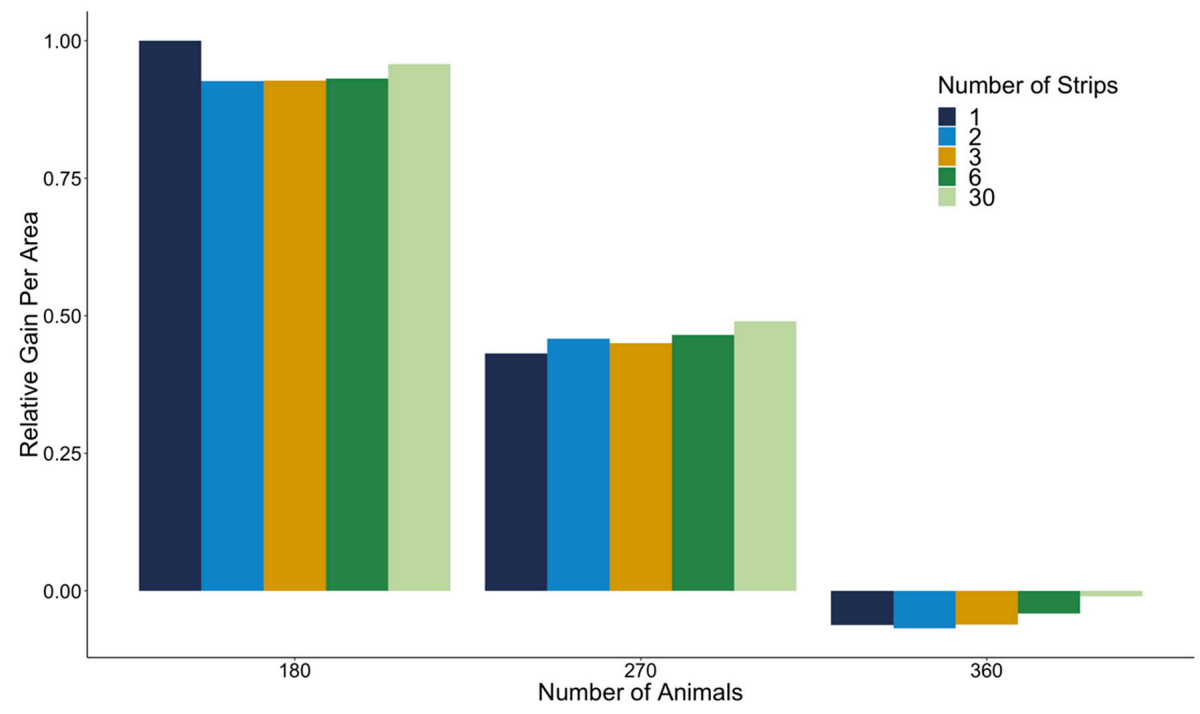

Figure 5. Effect of spatio-temporal distribution of animal density on relative gain per unit area under different numbers of sheep. Relative gain per unit area was calculated as average daily gain multiplied by number of animals per unit area, divided by the highest absolute gain per unit area of all treatments. 


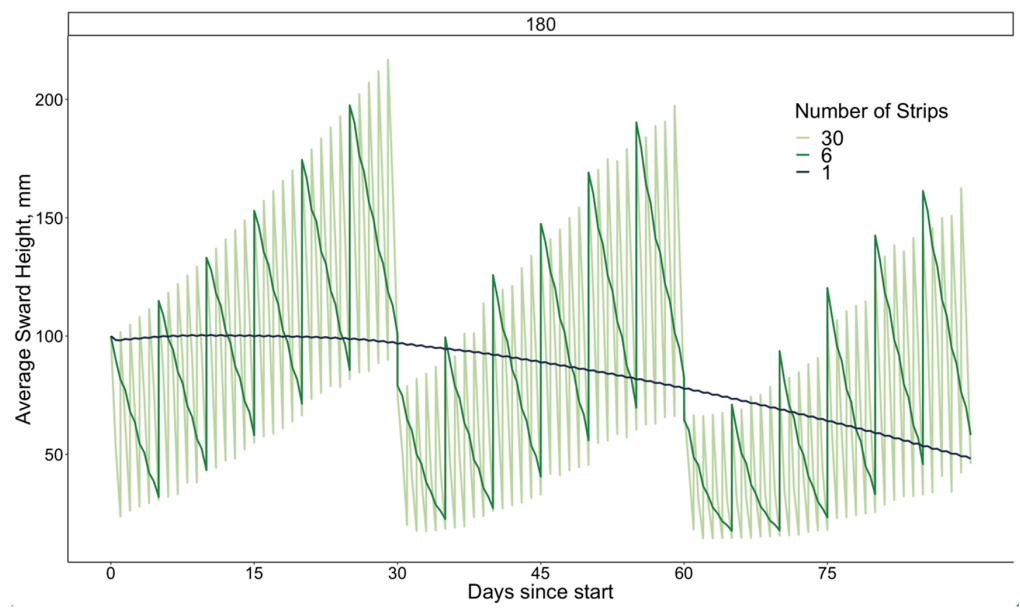

Figure 6. State of average sward height at the grazed strip every $12 \mathrm{~h}$ over the entire simulation period for three levels of numbers of strips for the lowest number of sheep (180). Each point on the line is the spatial average of heights within the strip.

\subsection{Herbage Allowance and Paddock Size}

In the third simulation set, average daily gain and relative gain per unit area increased with decreasing paddock size as herbage allowance was compensated by increasing herbage mass per unit area for all herbage allowances (Figure 7a,b). Even systems with lower herbage allowance had greater performance when compared to systems with greater herbage allowance but larger paddocks. For example, when herbage allowance was $0.7 \mathrm{~kg} \mathrm{DM} \mathrm{kg} \mathrm{BM}^{-1}$ and paddock area was $1 \mathrm{ha}$, relative gain per unit area was 0.77 (unitless, because it is the ratio of the observed value and the highest absolute gain per unit area of all treatments), whereas an herbage allowance of $1.5 \mathrm{~kg} \mathrm{DM} \mathrm{kg} \mathrm{BM}^{-1}$ and paddock size of 5 ha yielded a relative gain per unit area of 0.65 . Increasing paddock area had a negative effect on relative gain per unit area and average daily gain within each herbage allowance.

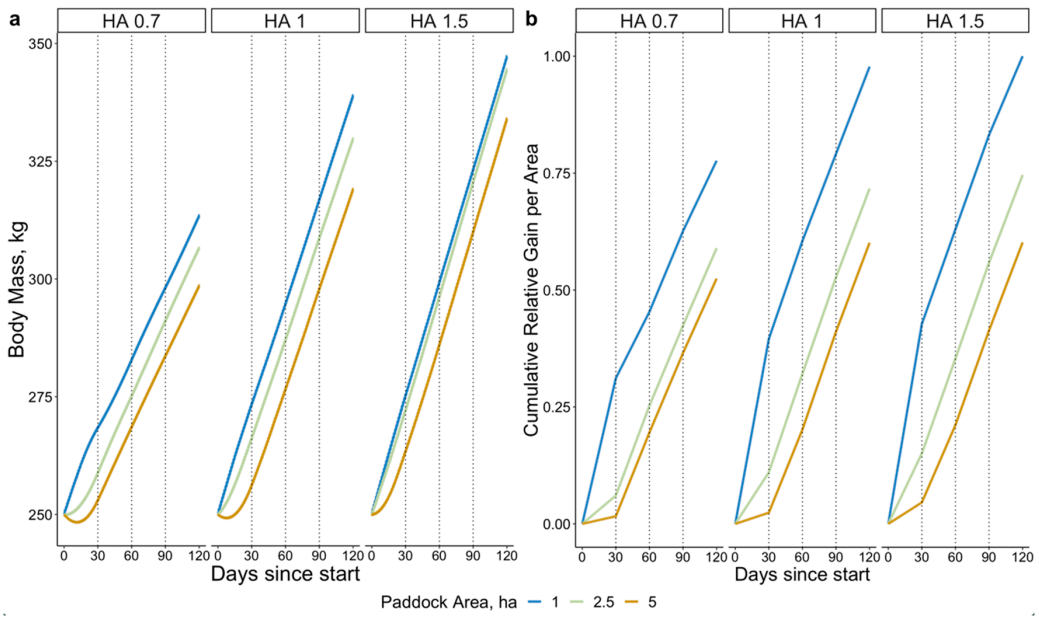

Figure 7. Effect of paddock size and herbage allowance (HA) on (a) body mass over time and (b) cumulative relative gain per unit area over time for cattle. Cumulative relative gain per unit area was calculated as the cumulative sum of average daily gain multiplied by the number of animals per unit area and divided by that of the treatment that had the highest value. All paddocks started with the same number of animals. Paddock areas were fixed over time and initial herbage allowance was achieved for each area by changing the average sward height and the corresponding distribution. As herbage mass per unit area was modified by growth and grazing, the number of animals was adjusted every 30 days (dashed line) to attain the nominal herbage allowance. 


\section{Discussion}

\subsection{Functional Response and Sward Heterogeneity}

The functional response exhibited a typical type II shape (i.e., instantaneous intake rate as function of sward height exhibits asymptotic shape) [45]. However, the model could produce a type IV functional response (i.e., instantaneous intake rate as function of sward height exhibits a dome shape) with plausible values of the parameters that describe the distribution of sward mass over height. This underlines the importance of the vertical distribution of sward mass, a characteristic that is rarely measured with enough detail.

Most studies of the functional response of herbivores use plant mass per unit area as an explanatory variable or the axis of resource abundance ([46-48], but some studies have used sward height as the $x$ axis $[49,50])$. However, given that bite depth is a fairly constant function of sward height, that bite area increases with sward height in a wide range of typical sward heights [51-53], and that herbage bulk density declines with increasing height in a species-specific pattern, the relationship between bite mass, intake rate, and herbage mass depends on sward structure. Furthermore, detailed models of functional responses of herbivores have been related only to average resource abundance [46,47]. Such models assume that grazers forage in a spatially homogenous resource. The present results show that greater heterogeneity, given by the horizontal distribution of height and the vertical distribution of mass, resulted in higher functional response because animals are able to select taller parts of the sward. Thus, these variables should be used as the determinant of functional response and incorporated into models with a grazing component.

Heterogeneity affords animals the opportunity to select, and thus modulates the relationship between average abundance and intake rate. Maximization of the instantaneous intake rate was done by ranking heights in decreasing order of instantaneous intake rate and adding them to the diet until the intake rate was maximized. The shortest height in the optimal diet and deviations from optimality (for example, due to imperfect discrimination of heights) was represented as a sigmoidal probability centered at the shortest height that would be selected according to the optimization of the intake rate with perfect discrimination of heights (Figure 3). Using a similar approach, Ungar and Noy-Meir [16] also reported that increases in horizontal variance at a given forage mass resulted in a higher instantaneous intake rate. Thus, functional response is not only related to average resource abundance, but also to its spatial distribution in high resolution.

The pattern of attack was set for maximization of the instantaneous intake rate based on the "zero-one rule" approach, where potential bites are fully rejected or accepted depending on their profitability [35]. However, herbivores can exhibit more pronounced partial preference [35] than what we used for the present simulations. Moreover, we ranked bite profitability using dry matter as currency. Variation in herbage quality can play a significant role in the profitability of bites and it will be included in forthcoming versions of the model.

Because the equilibrium and stability of grazing systems depend on the functional response [12,18] and sward heterogeneity can change the relationship between pasture growth and disappearance, the dynamics of heterogeneous plant-animal systems are different than homogeneous ones. The results shown for each functional response in Figure 2 apply only when sward structure and heterogeneity are constant, which would be rare in nature. In fact, longer runs of the model for any of the initial sward conditions simulated implicitly move smoothly across functional response curves, as heterogeneity changes over time. Spatial heterogeneity potentially invalidates the analysis of the stability and dynamics of grazing systems using functional responses and plant growth curves that are simple functions of average plant mass or height $[12,13]$. The existence of equilibrium states depends on the existence of stable height distributions where the functional response remains constant.

Our results demonstrate that spatial heterogeneity of sward height positively affects the instantaneous intake rate of herbivores because they are able to select the most profitable bites. Resource heterogeneity is an inherent characteristic of grazing systems; however, some grazing 
management guidelines still recommend sward homogenization through cutting and promote "non-selective" grazing. Conversely, we suggest that grazing research and management should incorporate resource heterogeneity into the design of grazing systems. Moreover, grazing experiments should include a description of the spatial heterogeneity, or at least a histogram of sward height for each treatment.

\subsection{Spatio-Temporal Distribution of Grazing}

Model results indicate that weight gain per animal and per unit area were not affected by the spatio-temporal distribution of animal density in a biologically significant manner within the range of conditions simulated, although there were small numerical differences. Although the sheep model in different treatments created and experienced different sward height distributions over time, sward differences did not translate to differences in animal performance across systems. Although herbivores responded positively to resource heterogeneity in the short term (Figure 2), heterogeneity effects were compensated for or diluted when the temporal scale of comparison was taken into account and increased to encompass several days. At the longer time scale of several days, mechanisms such as increased grazing time and digestive limitation interact, decreasing the effect of changes in instantaneous intake rate. Because foraging is a scale-dependent process in time and space [54], herbivores respond non-linearly to resource heterogeneity according to the temporal scale of observation. This finding is in agreement with Carvalho et al. [55], who found a weak relationship between short-term ingestive behavior variables and monthly animal performance.

Several studies argue that rotational stocking is superior to continuous stocking because it promotes resource homogeneity within paddocks after grazing, which increases animal performance by preventing the formation of areas that are over- or under grazed. Indeed, as previously reported by Barnes et al. [56], homogeneity within and heterogeneity between paddocks increased with an increasing number of strips in our simulations. Studies of the interaction between patch burn and grazing align with our results, also demonstrating the importance of animal density to create heterogeneity in space and time [57], as well as the buffer effect of heterogeneity to stabilize livestock production under extreme climatic conditions [58]. However, in our simulations, the number of strips had very little impact on animal and system performance. On the other hand, from a resource management perspective, sward heterogeneity between strips created by differences in animal density can be a tool to promote the reseeding of desirable grasses, control weeds [59], or provide habitat for wildlife. More simply, it should be obvious that the desirable level of homogeneity or heterogeneity depends on what one is trying to achieve with the stocking method.

As sward growth rate is a function of the sward state, one of the rationales to favor rotational stocking is that it allows control of sward state, growth rate, and animal production [60]. However, this explanation disregards the fact that the intensity of defoliation at the plant level is not susceptible to management by rotation of stocking. Bites are discrete events whose intensity is closely controlled by local sward height and density, and thus any system of grazing management, even continuous stocking, is "rotational" at plant level [9]. The frequency with which a plant is defoliated depends mainly on animal density [61] and can only be partially controlled by determining the number of animals, paddock area, and timing and duration of grazing periods. Moreover, it is likely that the impact of defoliation on average plant growth per unit area depends on the specific spatial pattern of defoliation. Growth and use of resources by taller plants located near defoliated plants is boosted by competitive release, thus ameliorating the total effect of uneven defoliation on community-level productivity $[62,63]$.

In a detailed review, Briske et al. [64] compared stocking methods and did not find consistent difference in herbage production, yield per animal, and unit of area between methods. However, most of the research reviewed was conducted at scales smaller $(<1 \mathrm{ha})$ than commercial paddocks (20-500 ha). In a large experiment aiming to compare responses of vegetation and cattle to stocking methods in ranch-scale paddocks (130 ha), Augustine et al. [65] reported that neither animal performance nor desirable grass production resulted in rotational stocking surpassing continuous 
stocking. These works compared stocking methods by changing animal density and paddock size simultaneously, although these factors are in fact independent. To our knowledge, the hypothesis that stocking methods cause differences in performance when paddock size is kept constant has not yet been tested experimentally.

While our results indicate that spatial distribution of animal density over paddocks does not affect animal performance, some models that assume defoliation and growth as spatially homogenous processes found differences between stocking methods. Using a differential equation model with two functions (growth and consumption rates), Noy-Meir [66] compared continuous stocking to rotational stocking with different combinations of timing and duration of grazing and resting periods, as well as under different animal densities. Daily intake was largely determined by the timing and duration of grazing periods, and rotational was better than continuous stocking with high animal density. In an extended version of Noy-Meir's model, Wang et al. [67] found that a multiple-paddock system yielded higher forage intake per animal than continuous stocking in a single paddock. The question that emerges is: Why do our results differ from predictions of non-spatial models? The fundamental difference is caused by a scaling error, because growth and consumption rates are not strictly related to the average state of the vegetation at paddock scale as is assumed in spatially homogenous models [19].

In our model each biting event removes $20-30 \%$ of the herbage mass at the bite location almost instantly, rapidly and drastically modifying height and growth rate in the grazed area. Although bite depth is $50 \%$ of sward height, herbage bulk density decreases exponentially as a function of height, and therefore the mass of herbage removed per unit bite area is less than $50 \%$ of the total mass per unit area available. Conversely, non-spatial models imply that the amount of mass removed by each bite is instantly spread across the entire paddock, with little impact on growth rate. The second source of differences is that the functional response varies with heterogeneity and for any given average sward height, animals can select areas more profitable than the average (Figure 2).

The model used in this paper assumes that herbage nutritive value is constant and spatially homogeneous, whereas in reality, sward chemical composition is heterogeneous in time and space. There is strong evidence that chemical composition varies with the time of day [68,69], phenological stages [70], and the vertical position in the canopy [22]. Therefore, the results of the present model are applicable to nutritionally homogeneous swards with limited phenological change. The effects of incorporating mechanisms for change in herbage quality are the subject of forthcoming work.

One of the most discussed dilemmas in grazing science are the pros and cons of managing animal density over time and space. In agreement with empirical results [64] and contrary to non-spatial model results $[66,67]$, our simulations using a spatial model do not provide evidence of superiority in yield in favor of any method. Thus, from the point of view of the practical application of increasing production, our results do not suggest that any specific design of spatio-temporal distribution of animal density should be promoted. On the other hand, modifications to the spatio-temporal distribution of animals can be used to control vegetation heterogeneity at paddock-to-landscape scales.

\subsection{Herbage Allowance and Paddock Size}

As expected, when herbage mass per unit area (which in the model translates into height) is traded off with paddock size to maintain herbage allowance, animal performance is changed, particularly in swards with short average height. Herbage allowance is a result of herbage mass per unit area, number of animals, animal liveweight, and paddock area. Part of its usefulness is that it is a metric that integrates all of its components. Unfortunately, its limitations as a predictor and cause of animal performance are also caused by the integration, which hides the specific combination of its factors. Animal performance relative to individual potential is determined mostly by daily intake rate and diet quality. Intake rate is largely controlled by herbage mass per unit area over a wide range of values of this component of herbage allowance. Gregorini et al. [71] reported a similar pattern, with herbage allowance having minor effect on daily dry matter intake when compared to sward height. Thus, when herbage mass per unit area is in the range where it dominates the control of daily intake, 
changes in herbage allowance achieved by changing the other factors do not have much effect on animal performance unless paddock area is small relative to the expected total intake by the group of animals during the period of occupation. This is what our simulations represented clearly.

Most of the difference between systems with the same herbage allowance occurred before the first adjustment of animal density to maintain the nominal herbage allowance (Figure 7a,b), when sward height was markedly contrasting and while the systems were not in equilibrium and differed markedly in sward heights. At the beginning, the sward height distribution was unstable and moved smoothly towards equilibrium state, and after adjustment with "put-and-take" animals, the systems reached equilibria with different stable height distributions (Figure 8). The frequency distribution was fairly similar to a Gamma distribution, with increasing frequency of short swards as the animal density increases, in agreement with observations by Shiyomi et al. [72]. Each animal density had a stable state with a particular sward height distribution, whereby heterogeneity increased as animal density decreased. Previous studies with a non-spatial model suggested a "dual stability" [12]. In another spatial model, Schwinning \& Parsons [18] found that dual stability occurs only for intermediate stocking density, whereas low and high stocking present one stable state.

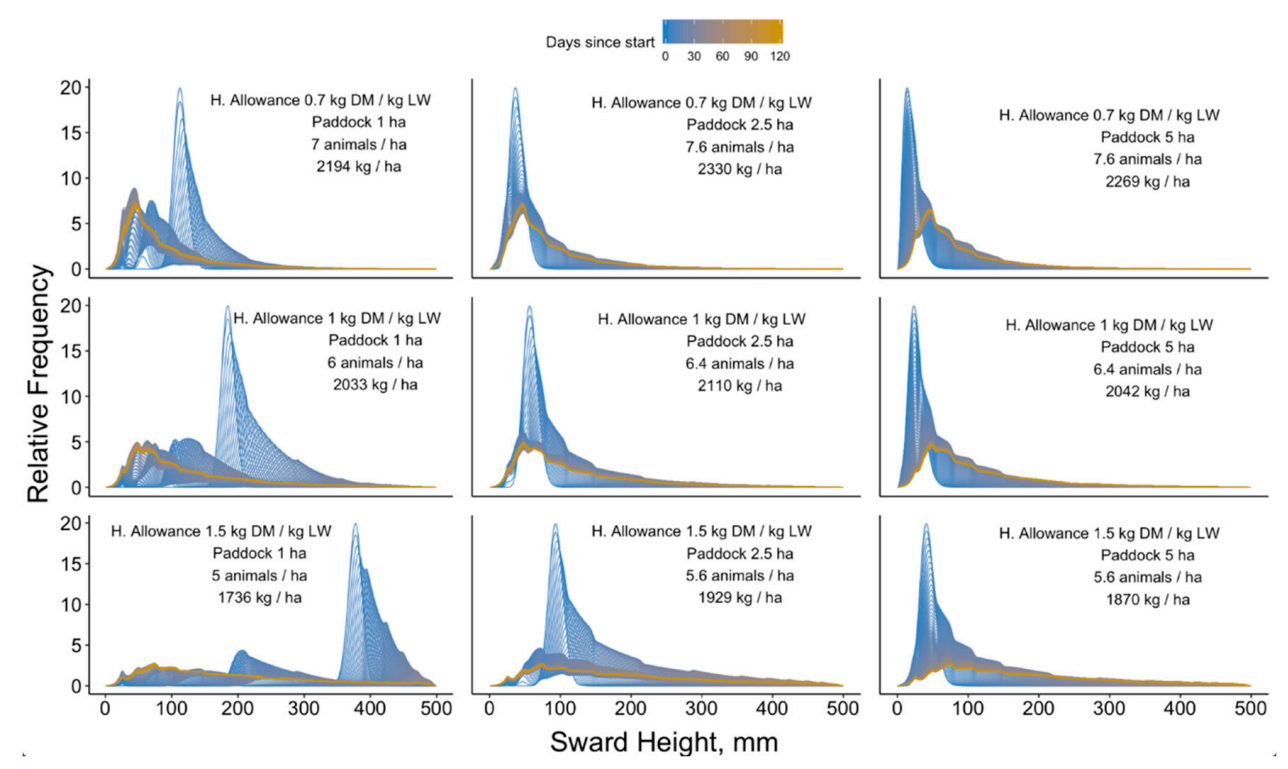

Figure 8. Sward height distribution over the entire grazing season of systems managed with herbage allowances of $0.7,1$, and $1.5 \mathrm{~kg}$ DM kg BW and paddock sizes of 1, 2.5, and 5 ha stocked with cattle. Each panel refers to one combination of herbage allowance and paddock size. The number of animals and $\mathrm{kg}$ of body mass per unit area at the end of simulations are written. Each line represents the frequency distribution of heights for one day, where day 1 is blue and day 120 is yellow. Most of the lines that appear are blue because after the systems reach equilibria, the yellow lines overlap.

Thus, herbage allowance is not sufficient as a predictor of animal performance because any value of herbage allowance can be achieved for any given vegetation state simply by changing the paddock area and number of animals. Over time, sward height will tend towards a stable height distribution determined by herbage allowance. Therefore, herbage allowance and sward height (or mass) cannot be controlled independently. This finding suggests that grazing experiments should start in conditions close to equilibrium (i.e., sward state and animal density) to avoid most differences due to factors other than herbage allowance. Moreover, these results also underline the importance of a detailed evaluation and description of sward height distribution in grazing experiments. Whereas some meta-analyses that focused on grazing behavior [73] or production [74] used herbage allowance as a predictor, we argue that herbage allowance is an insufficient metric to determine the grazing mechanisms that link pasture growth and animal performance. Finally, more than using a single variable to describe and manage 
systems, new approaches for grazing management should explore all management variables that can be controlled, such as number, mass and species of animals, timing and duration of grazing and rest periods, and paddock area and shape.

\section{Conclusions}

We created a model that integrates known mechanisms of bite formation and intake with very high temporal and spatial resolution and used it to determine how those mechanisms mediate responses to some typical factors of grazing management in realistic swards with spatial heterogeneity in height. Sward height heterogeneity resulted in higher short-term intake rate and determined the height of the resulting type II functional response. Studies of effects of sward height in grazing systems should, at the very least, include a description of the statistical distribution of sward height. Spatial distribution of animal density as controlled by fencing did not affect animal performance, but it can be used to manage resource heterogeneity. Under equilibrium conditions, sward height or mass and herbage allowance cannot be controlled independently.

The model yielded realistic results for swards that are homogeneous in quality, and future improvements will represent a broader set of swards and conditions. A more detailed vegetation growth and quality model will be developed to account for differences in unit leaf rate due to age and nitrogen content. Plant mass will be structured by both height and quality, which will influence diet selection and animal performance. Finally, resource patchiness and search mechanisms will open the potential to see the effects of heterogeneity across multiple scales.

Author Contributions: Conceptualization, E.A.L. and A.P.-P.; methodology, E.A.L.; software, E.A.L. and A.P.-P.; validation, A.P.-P.; formal analysis, A.P.-P. and E.A.L.; investigation, A.P.-P. and E.A.L.; resources, E.A.L.; data curation, A.P.-P. and P.C.d.F.C.; writing—original draft preparation, A.P.-P.; writing—review and editing, E.A.L. and P.C.d.F.C.; visualization, A.P.-P.; supervision, E.A.L. and P.C.d.F.C.; project administration, P.C.d.F.C. and E.A.L.; funding acquisition, P.C.d.F.C. and E.A.L. All authors have read and agreed to the published version of the manuscript.

Funding: This research was partially funded by USDA-NIFA grant 2010-38415-21906 to E.A.L. A.P.-P. was funded by a scholarship from CAPES, Brazil and by multiple grants for E.A.L. from UC Davis. P.C.d.F.C. was funded by a fellowship from CNPq, Brazil.

Acknowledgments: Pablo Chilibroste provided advice on some of the model parameters.

Conflicts of Interest: The authors declare no conflict of interest.

\section{Appendix A}

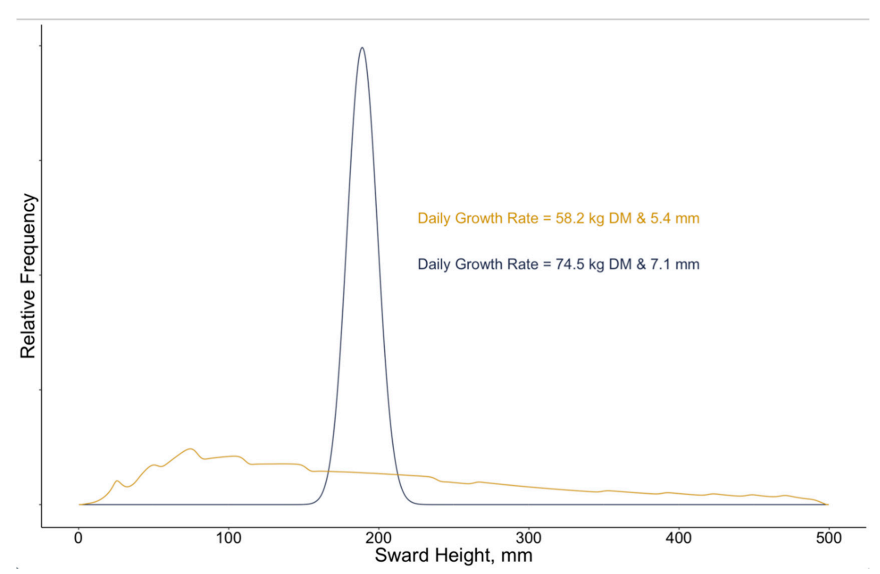

Figure A1. Effect of sward heterogeneity on growth rate. Both sward height distributions have the same average $(189 \mathrm{~mm})$, but different shapes. In this case, the growth rate of the more heterogeneous swards (yellow line) is lower because most paddock areas have heights that are very limiting to growth rate. 


\section{References}

1. Laca, E.A. New approaches and tools for grazing management. Rangel. Ecol. Manag. 2009, 62, $407-417$. [CrossRef]

2. Benvenutti, M.A.; Cangiano, C.A. Características de las Pasturas y su Relación con el Comportamiento Ingestivo y Consumo en Pastoreo. In Producción Animal en Pastoreo; Cangiano, C.A., Brizuela, M.A., Eds.; Ediciones INTA: Buenos Aires, Argentina, 2011; pp. 259-290.

3. Carvalho, P.C.F. Harry Stobbs Memorial Lecture: Can grazing behavior support innovations in grassland management? Trop. Grassl. 2013, 1, 137-155. [CrossRef]

4. Hutchings, N.J.; Gordon, I.J. A dynamic model of herbivore-plant interactions on grasslands. Ecol. Model. 2001, 136, 209-222. [CrossRef]

5. Gordon, I.J.; Benvenutti, M. Food in 3D: How Ruminant Livestock Interact with Sown Sward Architecture at the Bite Scale. In Feeding in Domestic Vertebrates: From Structure to Behaviour; Bell, V., Ed.; CABI Publishing: Wallingford, CT, USA, 2006; pp. 263-277.

6. Oñatibia, G.R.; Aguiar, M.R. Paddock size mediates the heterogeneity of grazing impacts on vegetation. Rangel. Ecol. Manag. 2018, 71, 470-480. [CrossRef]

7. Larson-Praplan, S.; George, M.R.; Buckhouse, J.C.; Laca, E.A. Spatial and temporal domains of scale of grazing cattle. Anim. Prod. Sci. 2015, 55, 284-297. [CrossRef]

8. Garcia, F.; Carrère, P.; Soussana, J.F.; Baumont, R. Characterisation by fractal analysis of foraging paths of ewes grazing heterogeneous swards. Appl. Anim. Behav. Sci. 2005, 93, 19-37. [CrossRef]

9. Cid, M.S.; Brizuela, M.A. Heterogeneity in tall fescue pastures created and sustained by cattle grazing. Rangel. Ecol. Manag. 1998, 51, 644-649. [CrossRef]

10. Nunes, P.A.D.A.; Bredemeier, C.; Bremm, C.; Caetano, L.A.M.; de Almeida, G.M.; de Souza Filho, W.; Anghinoni, I.; Carvalho, P.C.D.F. Grazing intensity determines pasture spatial heterogeneity and productivity in an integrated crop-livestock system. Grassl. Sci. 2019, 65, 49-59. [CrossRef]

11. Parsons, A.J.; Carrère, P.; Schwinning, S. Dynamics of Heterogeneity in A Grazed Sward. In Grassland Ecophysiology and Grazing Ecology; Lemaire, G., Hodgson, J., Moraes, A., Nabinger, C., Carvalho, P.C.F., Eds.; CABI Publishing: Wallingford, CT, USA, 2000; pp. 289-316.

12. Semmartin, M.; Oesterheld, M. Effects of grazing pattern and nitrogen availability on primary productivity. Oecologia 2001, 126, 225-230. [CrossRef]

13. Parsons, A.J.; Dumont, B. Spatial heterogeneity and grazing processes. Anim. Res. 2003, 52, 161-179. [CrossRef]

14. Noy-Meir, I. Stability of grazing systems: An application of predator-prey graphs. J. Ecol. 1975, 63, 459-481. [CrossRef]

15. Ungar, E.D. Perspectives on the concept of rangeland carrying capacity, and their exploration by means of Noy-Meir's two-function model. Agric. Syst. 2019, 173, 403-413. [CrossRef]

16. Ungar, E.D.; Noy-Meir, I. Herbage intake in relation to availability and sward structure: Grazing processes and optimal foraging. J. Appl. Ecol. 1988, 25, 1045-1062. [CrossRef]

17. Parsons, A.J.; Thornley, J.H.; Newman, J.; Penning, P.D. A mechanistic model of some physical determinants of intake rate and diet selection in a two-species temperate grassland sward. Funct. Ecol. 1994, 8, 187-204. [CrossRef]

18. Schwinning, S.; Parsons, A.J. The stability of grazing systems revisited: Spatial models and the role of heterogeneity. Funct. Ecol. 1999, 13, 737-747. [CrossRef]

19. Parsons, A.J.; Schwinning, S.; Carrère, P. Plant growth functions and possible spatial and temporal scaling errors in models of herbivory. Grass Forage Sci. 2001, 56, 21-34. [CrossRef]

20. Baumont, R.; Cohen-Salmon, D.; Prache, S.; Sauvant, D. A mechanistic model of intake and grazing behaviour in sheep integrating sward architecture and animal decisions. Anim. Feed Sci. Technol. 2004, 112, 5-28. [CrossRef]

21. Gregorini, P.; Beukes, P.C.; Romera, A.J.; Levy, G.; Hanigan, M.D. A model of diurnal grazing patterns and herbage intake of a dairy cow, MINDY: Model description. Ecol. Model. 2013, 270, 11-29. [CrossRef]

22. Delagarde, R.; Peyraud, J.L.; Delaby, L.; Faverdin, P. Vertical distribution of biomass, chemical composition and pepsin-Cellulase digestibility in a perennial ryegrass sward: Interaction with month of year, regrowth age and time of day. Anim. Feed Sci. Technol. 2000, 84, 49-68. [CrossRef] 
23. Silva, D.F.F.D. A Altura que Maximiza a Taxa de Ingestão em Azevém Anual (Lolium Multiflorum Lam.) é Afetada Pela Existência de Palhada Quando o Método de Estabelecimento é em Semeadura Direta? UFPR: Curitiba, Brazil, 2013.

24. Ellner, S.P.; Childs, D.Z.; Rees, M. Data-Driven Modelling of Structured Populations. In A Practical Guide to the Integral Projection Model; Springer: Cham, Switzerland, 2016.

25. Förster, L.; Grant, J.; Michel, T.; Ng, C.; Barth, S. Growth under cold conditions in a wide perennial ryegrass panel is under tight physiological control. PeerJ 2018, 6, 5520. [CrossRef]

26. Cumming, D.H.; Cumming, G.S. Ungulate community structure and ecological processes: Body size, hoof area and trampling in African savannas. Oecologia 2003, 134, 560-568. [CrossRef]

27. Linnane, M.I.; Brereton, A.J.; Giller, P.S. Seasonal changes in circadian grazing patterns of Kerry cows (Bos taurus) in semi-feral conditions in Killarney National Park, Co. Kerry, Ireland. Appl. Anim. Behav. Sci. 2001, 71, 277-292. [CrossRef]

28. Hirata, M.; Higashiyama, M.; Hasegawa, N. Diurnal pattern of excretion in grazing cattle. Livest. Sci. 2011, 142, 23-32. [CrossRef]

29. Krizsan, S.J.; Ahvenjärvi, S.; Huhtanen, P. A meta-analysis of passage rate estimated by rumen evacuation with cattle and evaluation of passage rate prediction models. J. Dairy Sci. 2010, 93, 5890-5901. [CrossRef]

30. Demment, M.W.; Van Soest, P.J. A nutritional explanation for body-size patterns of ruminant and nonruminant herbivores. Am. Nat. 1985, 125, 641-672. [CrossRef]

31. Chilibroste, P.; Tamminga, S.; Boer, H. Effects of length of grazing session, rumen fill and starvation time before grazing on dry-matter intake, ingestive behaviour and dry-matter rumen pool sizes of grazing lactating dairy cows. Grass Forage Sci. 1997, 52, 249-257. [CrossRef]

32. Illius, A.W.; Gordon, I.J. The allometry of food intake in grazing ruminants. J. Anim. Ecol. 1987, 56, 989-999. [CrossRef]

33. Laca, E.A.; Ungar, E.D.; Demment, M.W. Mechanisms of handling time and intake rate of a large mammalian grazer. Appl. Anim. Behav. Sci. 1994, 39, 3-19. [CrossRef]

34. Rook, A.J.; Harvey, A.; Parsons, A.J.; Orr, R.J.; Rutter, S.M. Bite dimensions and grazing movements by sheep and cattle grazing homogeneous perennial ryegrass swards. Appl. Anim. Behav. Sci. 2004, 88, 227-242. [CrossRef]

35. Stephens, D.W.; Krebs, J.R. Foraging Theory; Princeton University Press: Princeton, NJ, USA, 1986.

36. Brosh, A.; Henkin, Z.; Ungar, E.D.; Dolev, A.; Orlov, A.; Yehuda, Y.; Aharoni, Y. Energy cost of cows' grazing activity: Use of the heart rate method and the Global Positioning System for direct field estimation. J. Anim. Sci. 2006, 84, 1951-1967. [CrossRef] [PubMed]

37. Brosh, A.; Henkin, Z.; Ungar, E.D.; Dolev, A.; Shabtay, A.; Orlov, A.; Yehuda, Y.; Aharoni, Y. Energy cost of activities and locomotion of grazing cows: A repeated study in larger plots. J. Anim. Sci. 2010, 88, 315-323. [CrossRef]

38. National Research Council. Nutrient Requirements of Beef Cattle; National Academies Press: Washington, DC, USA, 2016.

39. National Research Council. Nutrient Requirements of Small Ruminants: Sheep, Goats, Cervids, and New World Camelids; National Academies Press: Washington, DC, USA, 2007.

40. Piñeiro, G.; Perelman, S.; Guerschman, J.P.; Paruelo, J.M. How to evaluate models: Observed vs. predicted or predicted vs. observed? Ecol. Model. 2008, 216, 316-322. [CrossRef]

41. Orr, R.J.; Rutter, S.M.; Yarrow, N.H.; Champion, R.A.; Rook, A.J. Changes in ingestive behaviour of yearling dairy heifers due to changes in sward state during grazing down of rotationally stocked ryegrass or white clover pastures. Appl. Anim. Behav. Sci. 2004, 87, 205-222. [CrossRef]

42. Mott, G.O.; Lucas, H.L. The design, conduct and interpretation of grazing trials on cultivated and improved pastures. Int. Grassl. Congr. 1952, 6, 1380-1395.

43. Sollenberger, L.E.; Moore, J.E.; Allen, V.G.; Pedreira, C.G. Reporting forage allowance in grazing experiments. Crop Sci. 2005, 45, 896-900. [CrossRef]

44. Rouquette, F.M., Jr. Invited review: The roles of forage management, forage quality, and forage allowance in grazing research. Prof. Anim. Sci. 2016, 32, 10-18. [CrossRef]

45. Holling, C.S. Some characteristics of simple types of predation and parasitism. Can. Entomol. 1959, 91, 385-398. [CrossRef]

46. Spalinger, D.E.; Hobbs, N.T. Mechanisms of foraging in mammalian herbivores: New models of functional response. Am. Nat. 1992, 140, 325-348. [CrossRef] 
47. Gross, J.E.; Shipley, L.A.; Hobbs, N.T.; Spalinger, D.E.; Wunder, B.A. Functional response of herbivores in food-concentrated patches: Tests of a mechanistic model. Ecology 1993, 74, 778-791. [CrossRef]

48. Thompson Hobbs, N.; Gross, J.E.; Shipley, L.A.; Spalinger, D.E.; Wunder, B.A. Herbivore functional response in heterogeneous environments: A contest among models. Ecology 2003, 84, 666-681. [CrossRef]

49. Bergman, C.M.; Fryxell, J.M.; Gates, C.C. The effect of tissue complexity and sward height on the functional response of wood bison. Funct. Ecol. 2000, 14, 61-69. [CrossRef]

50. Mezzalira, J.C.; Bonnet, O.J.; Carvalho, P.C.D.F.; Fonseca, L.; Bremm, C.; Mezzalira, C.C.; Laca, E.A. Mechanisms and implications of a type IV functional response for short-term intake rate of dry matter in large mammalian herbivores. J. Anim. Ecol. 2017, 86, 1159-1168. [CrossRef]

51. Ungar, E.D.; Genizi, A.; Demment, M.W. Bite dimensions and herbage intake by cattle grazing short hand-constructed swards. Agron. J. 1991, 83, 973-978. [CrossRef]

52. Laca, E.A.; Ungar, E.D.; Seligman, N.; Demment, M.W. Effects of sward height and bulk density on bite dimensions of cattle grazing homogeneous swards. Grass Forage Sci. 1992, 47, 91-102. [CrossRef]

53. Cangiano, C.A.; Galli, J.R.; Pece, M.A.; Dichio, L.; Rozsypalek, S.H. Effect of liveweight and pasture height on cattle bite dimensions during progressive defoliation. Aust. J. Agric. Res. 2002, 53, 541-549. [CrossRef]

54. Milne, B.T.; Turner, M.G.; Wiens, J.A.; Johnson, A.R. Interactions between the fractal geometry of landscapes and allometric herbivory. Theor. Popul. Biol. 1992, 41, 337-353. [CrossRef]

55. Carvalho, P.D.F.; Bremm, C.; Mezzalira, J.C.; Fonseca, L.; Da Trindade, J.K.; Bonnet, O.J.F.; Tischler, M.; Genro, T.C.M.; Nabinger, C.; Laca, E.A. Can animal performance be predicted from short-term grazing processes? Anim. Prod. Sci. 2015, 55, 319-327. [CrossRef]

56. Barnes, M.K.; Norton, B.E.; Maeno, M.; Malechek, J.C. Paddock size and stocking density affect spatial heterogeneity of grazing. Rangel. Ecol. Manag. 2008, 61, 380-388. [CrossRef]

57. Raynor, E.J.; Griffith, C.D.; Twidwell, D.; Schacht, W.H.; Wonkka, C.L.; Roberts, C.P.; Bielski, C.L.; Debinski, D.M.; Miller, J.R. The emergence of heterogeneity in invasive-dominated grassland: A matter of the scale of detection. Landsc. Ecol. 2018, 33, 2103-2119. [CrossRef]

58. Allred, B.W.; Scasta, J.D.; Hovick, T.J.; Fuhlendorf, S.D.; Hamilton, R.G. Spatial heterogeneity stabilizes livestock productivity in a changing climate. Agric. Ecosyst. Environ. 2014, 193, 37-41. [CrossRef]

59. Bailey, D.W.; Mosley, J.C.; Estell, R.E.; Cibils, A.F.; Horney, M.; Hendrickson, J.R.; Walker, J.W.; Launchbaugh, K.L.; Burritt, E.A. Synthesis Paper: Targeted Livestock Grazing: Prescription for Healthy Rangelands. Rangel. Ecol. Manag. 2019, 72, 865-877. [CrossRef]

60. Fulkerson, W.J.; Donaghy, D.J. Plant-soluble carbohydrate reserves and senescence-key criteria for developing an effective grazing management system for ryegrass-based pastures: A review. Aust. J. Exp. Agric. 2001, 41, 261-275. [CrossRef]

61. Wade, M.H.; Carvalho, P.D.F. Defoliation Patterns and Herbage Intake on Pastures. In Grassland Ecophysiology and Grazing Ecology; Lemaire, G., Hodgson, J., Moraes, A., Nabinger, C., Carvalho, P.C.F., Eds.; CABI Publishing: Wallingford, CT, USA, 2000; pp. 233-248.

62. Mueggler, W.F. Influence of competition on the response of bluebunch wheatgrass to clipping. J. Range Manag. 1972, 25, 88-92. [CrossRef]

63. Gdara, A.O.; Hart, R.H.; Dean, J.G. Response of tap- and creeping-rooted alfalfas to defoliation patterns. J. Range Manag. 1991, 44, 22-26. [CrossRef]

64. Briske, D.D.; Derner, J.D.; Brown, J.R.; Fuhlendorf, S.D.; Teague, W.R.; Havstad, K.M.; Gillen, R.L.; Ash, A.J.; Willms, W.D. Rotational grazing on rangelands: Reconciliation of perception and experimental evidence. Rangel. Ecol. Manag. 2008, 61, 3-17. [CrossRef]

65. Augustine, D.J.; Derner, J.D.; Fernández-Giménez, M.E.; Porensky, L.M.; Wilmer, H.; Briske, D.D. Adaptive, multipaddock rotational grazing management: A ranch-scale assessment of effects on vegetation and livestock performance in semiarid rangeland. Rangel. Ecol. Manag. 2020, in press. [CrossRef]

66. Noy-Meir, I. Rotational grazing in a continuously growing pasture: A simple model. Agric. Syst. 1976, 1, 87-112. [CrossRef]

67. Wang, T.; Teague, W.R.; Park, S.C. Evaluation of continuous and multipaddock grazing on vegetation and livestock performance-A modeling approach. Rangel. Ecol. Manag. 2016, 69, 457-464. [CrossRef]

68. Griggs, T.C.; MacAdam, J.W.; Mayland, H.F.; Burns, J.C. Temporal and vertical distribution of nonstructural carbohydrate, fiber, protein, and digestibility levels in orchardgrass swards. Agron. J. 2007, 99, 755-763. [CrossRef] 
69. Gregorini, P.; Eirin, M.; Refi, R.; Ursino, M.; Ansin, O.E.; Gunter, S.A. Timing of herbage allocation in strip grazing: Effects on grazing pattern and performance of beef heifers. J. Anim. Sci. 2006, 84, 1943-1950. [CrossRef]

70. Chen, A.; Bryant, R.H.; Edwards, G.R. Morphology and nutritive value of perennial ryegrass cultivars at different phenological stages. Grass Forage Sci. 2019, 74, 576-581. [CrossRef]

71. Gregorini, P.; Provenza, F.D.; Villalba, J.J.; Beukes, P.C.; Forbes, M.J. Dynamics of forage ingestion, oral processing and digesta outflow from the rumen: A development in a mechanistic model of a grazing ruminant, MINDY. J. Agric. Sci. 2018, 156, 980-995. [CrossRef]

72. Shiyomi, M.; Okada, M.; Takahashi, S.; Tang, Y. Spatial pattern changes in aboveground plant biomass in a grazing pasture. Ecol. Res. 1998, 13, 313-322. [CrossRef]

73. Boval, M.; Sauvant, D. Ingestive behaviour of grazing ruminants: Meta-analysis of the components of bite mass. Anim. Feed Sci. Technol. 2019, 251, 96-111. [CrossRef]

74. Pérez-Prieto, L.A.; Delagarde, R. Meta-analysis of the effect of pasture allowance on pasture intake, milk production, and grazing behavior of dairy cows grazing temperate grasslands. J. Dairy Sci. 2013, 96, 6671-6689. [CrossRef] [PubMed]

Publisher's Note: MDPI stays neutral with regard to jurisdictional claims in published maps and institutional affiliations.

(C) 2020 by the authors. Licensee MDPI, Basel, Switzerland. This article is an open access article distributed under the terms and conditions of the Creative Commons Attribution (CC BY) license (http://creativecommons.org/licenses/by/4.0/). 